\title{
Role of re-seeding and seedling recruitment for sustainable Lotus corniculatus based pastures in dry hill and high country
}

\author{
W.J. FRASER', S.C. OGDEN ${ }^{2}$, R.F. WOODMAN ${ }^{1}$ and W.L. LOWTHER ${ }^{1}$ \\ ${ }^{1}$ AgResearch, Invermay Agricultural Centre, Mosgiel \\ ${ }^{2}$ MAF Quality Management, Lincoln
}

\begin{abstract}
Birdsfoot trefoil (Lotus corniculatus L.) is a species with considerable potential for hill and high country of the South Island; however, difficulties in maintaining satisfactory stands due to problems with persistence have been reported. Plant recruitment through natural reseeding is considered a necessary tool for the maintenance and improvement of birdsfoot trefoil stands in the USA, but research which investigates the role of soil seedbanks, seedling recruitment and stand management for improving the persistence of birdsfoot trefoil in the drier hill and high country of the South Island of New Zealand is limited. Two field experiments in the dry hill and high country of Otago monitored changes in stand populations and seedling emergence of birdsfoot trefoil under differing grazing management. At Ardlui Station on the Coastal Otago Plateau, seedling emergence was greatest in autumn rather than spring after spelling over the flowering period. Despite considerable numbers of autumn seedlings (128 seedlings $/ \mathrm{m}^{2}$ ), less than 1 seedling $/ \mathrm{m}^{2}$ survived to contribute to the stand after 12 months. Plant populations-did, however, increase in 199 1/92 following adequate rainfall in the previous autumn. Spring emerged seedlings did not survive through summer. At Omarama Station in the southern Mackenzie Basin, plant populations of birdsfoot trefoil continued to decline despite the presence of seedlings in spring and autumn. Results imply that natural reseeding cannot be relied upon to improve birdsfoot trefoil plant populations unless favourable climatic conditions prevail during spring or autumn.
\end{abstract}

Keywords: establishment, Lotus corniculatus, management, natural reseeding, persistence, seedling recruitment, soil seedbanks, survival

\section{Introduction}

Birdsfoot trefoil is a perennial forage legume widely used in North and South America and Europe (Seaney \& Henson 1970). It is a deep tap-rooted, non bloating and highly nutritive legume with potential for moderately fertile dry hill and high country in New Zealand, particularly where soil acidity limits the success of Iuceme (Scott \& Charlton 1983).

In areas of the USA where the perennial habit of birdsfoot trefoil is shortened by management (Van Keuren \& Davis 1968), environment or disease (Miller et al. 1964), natural reseeding is a management tool used successfully to contribute to long-term persistence (Taylor et al. 1973). Chapman et al. (1990) identified some factors limiting the success of birdsfoot trefoil in the hill and high country of New Zealand and commented on the need for investigation of natural reseeding as a practice to increase plant numbers and ensure stand longevity.

The aim of this paper is to investigate natural reseeding of birdsfoot trefoil in the drier hill and high country of the southern South Island, and the role of grazing management on seedling recruitment and stand persistence.

\section{Materials and methods}

\section{Ardlui}

Sampling_was_carried_out-on-Ardlui-Station, ${ }^{-} \mathbf{n}^{-}$the

Coastal Otago Plateau, within an experiment established following conventional cultivation in October 1987. The soil was a yellow-grey earth $(\mathrm{pH} 5.4)$ and $600 \mathrm{~mm}$ annual rainfall. Observations originate from two independent studies. The first used 20 permanent quadrats $\left(0.25 \mathrm{~m}^{2}\right)$ on $1750 \mathrm{~m}^{2}$ plots of Dryland (an experimental selection developed in the South Island high country (Widdup et al. 1987)) and Granger (a North American cultivar with semi-erect growth habit) birdsfoot trefoil on each of 3 replicates to assess plant and seedling-populations in-October rind May.

The second study investigated the role of grazing management on plant recruitment on the Dryland plots only using 2 grazing treatments. The grazing treatments consisted of (1) grazing throughout the flowering period, with normal grazing practices at other times and (2) summer spelling over the flowering period. Seedling counts were taken in October and May using 16 permanent quadrats $\left(0.25 \mathrm{~m}^{2}\right)$ per grazing treatment, and 2 seedlings per quadrat were marked using small rubber rings and survival assessed monthly. 


\section{Omarama}

Sampling was carried out on Omarama Station, on the southern Mackenzie Basin, within an experiment established following direct drilling in September 1987 (Keoghan et al. 1989). The soil was a yellow-brown earth (pH 5.5) and the annual rainfall was $520 \mathrm{~mm}$.

Plant and seedling counts were taken in October and May using 10 permanent quadrats $\left(0.25 \mathrm{~m}^{2}\right)$ on 85.6 $\mathrm{m}^{2}$ plots of Grasslands Goldie (a New Zealand-bred cultivar with semi-erect growth habit), Dryland, Granger and Empire (a North American cultivar with semiprostrate habit) birdsfoot trefoil on each of 3 replicates.

\section{Results}

\section{Ardlui}

Seedlings emerging during autumn 1990 and spring 1991 (4-year stand) failed to increase numbers in following seasons (Table 1). However, plant numbers increased in spring 1992 from autumn seedlings in both Dryland and Granger birdsfoot trefoil.
Grazing treatments were imposed after autumn 1989 counts when the stand was 18 months old (Table 2). In the following spring, seedling numbers were low. The ungrazed treatment increased seedling numbers significantly $(\mathbf{P}<0.01)$ in autumn 1990 , with 128 and 3.2 seedlings $/ \mathrm{m}^{2}$ in the ungrazed and grazed treatments respectively. After 12 months, all seedlings in the grazed treatment had died and although seedlings in the ungrazed treatment survived, numbers were less than 1 seedling $/ \mathrm{m}^{2}$, with the greatest seedling mortality occurring in the first 3 months. Spring seedling mortality was greatest soon after emergence and after 12 months no seedlings survived in either grazing treatment (Table 2).

\section{Omarama}

Following good initial establishment during the first season (Allan et al. 1991), there was a large decline in birdsfoot trefoil plant numbers by autumn 1989 (Table $3)$. The decline in plant numbers continued despite the regeneration of seedlings in both spring 1990 and autumn

Table 1 Establishment of Dryland and Granger birdsfoot trefoil on Ardlui Station, Central Otago Plateau under sheep grazing (numbers $/ \mathrm{m}^{*}$ ).

\begin{tabular}{lcccccccc}
\hline \multirow{2}{*}{ Treatment } & \multicolumn{2}{c}{ Autumn 1990} & \multicolumn{2}{c}{ Spring 1991} & \multicolumn{2}{c}{ Autumn 1991} & \multicolumn{2}{c}{ Spring 1992} \\
& Plant & Seedling & Plant & Seedling & Plant & Seedling & Plant & Seedling \\
\hline Dryland & 27.9 & 19.1 & 27.4 & 32.7 & 27.6 & 13.6 & 31.8 & 0 \\
Granger & 21.2 & 12.0 & 21.0 & 45.1 & 22.1 & 16.8 & 29.4 & 0 \\
SED & 2.75 & 6.38 & 3.06 & 17.34 & 2.24 & 3.04 & 3.16 & . \\
\hline
\end{tabular}

Table 2 Seedling emergence and survival of Dryland birdsfoot trefoil on Ardlui Station, Coastal Otago Plateau with and without sheep grazing (numbers $/ \mathrm{m}^{*}$ ).

\begin{tabular}{|c|c|c|c|c|c|c|c|c|c|c|c|c|}
\hline Treatment & \multicolumn{3}{|c|}{$\begin{array}{c}\text { Autumn } 1969- \\
\text { Emerging } \\
\text { After } 3 \text { After } 12 \\
\text { months months }\end{array}$} & \multicolumn{3}{|c|}{$\begin{array}{r}\text { Spring } 1990 \text {-.- Surviving -- } \\
\text { Emerging } \\
\text { After } 3 \text { Alter } 12 \\
\text { months months }\end{array}$} & \multicolumn{3}{|c|}{$\begin{array}{r}\text { Autumn } 1990- \\
\text { Emerging }-- \text { Surviving --- } \\
\text { After } 6 \text { After } 12 \\
\text { months months }\end{array}$} & Emerging & $\begin{array}{l}\text { pring } 199 \\
-- \text { Surv } \\
\text { After } 1 \\
\text { month }\end{array}$ & $\begin{array}{l}\text { iving --- } \\
\text { After 12 } \\
\text { months }\end{array}$ \\
\hline Grazed & 8.36 & 0 & 0 & 0.88 & 0 & 0 & 3.2 & 0.31 & 0 & 0 & 0 & 0 \\
\hline Ungrazed & 11.76 & 0.07 & 0.07 & 0.79 & 0.08 & 0 & 126.0 & 9.98 & 0.67 & 0.13 & 0.04 & 0 \\
\hline SED & 3.168 & - & , & 0.550 & " & 4 & 15.60 & - & . & & & \\
\hline
\end{tabular}

Table 3 Plant and seedling numbers of Grasslands Goldie, Dryland, Granger and Empire birdsfoot trefoil on Omarama Station, southern Mackenzie Basin, under sheep grazing (numbers $/ \mathrm{m}^{2}$ ).

\begin{tabular}{|c|c|c|c|c|c|c|c|c|c|c|c|c|c|}
\hline \multirow[b]{2}{*}{ Treatment } & \multirow{2}{*}{$\begin{array}{l}\text { Spring } 1987^{1} \\
\text { Plant }\end{array}$} & \multicolumn{2}{|c|}{ Autumn 1989} & \multicolumn{2}{|c|}{ Spring 1990} & \multicolumn{2}{|c|}{ Autumn 1990} & \multicolumn{2}{|c|}{ Spring 1991} & \multicolumn{2}{|c|}{ Autumn 1991} & \multicolumn{2}{|c|}{ Spring 1993} \\
\hline & & Plant & Seedling & Plant & Seedling & Plant & Seedling & Plant & Seedling & Plant & Seedling & Plant & Seedling \\
\hline \multicolumn{14}{|l|}{ Grasslands } \\
\hline Goldie & 69 & 6.07 & 7.94 & 6.80 & 1.07 & 6.27 & 1.07 & 4.40 & 3.33 & 2.67 & 0.80 & 2.53 & 0 \\
\hline Dryland & 102 & 4.00 & 0.67 & 5.33 & 4.27 & 4.40 & 0.93 & 4.93 & 2.80 & 3.87 & 0 & 3.47 & 0 \\
\hline Granger & 34 & 1.07 & 0.80 & 1.07 & 2.13 & 0.93 & 0 & 0.80 & 1.07 & 0.53 & 0 & 0.67 & 0 \\
\hline Empire & 60 & 0.27 & 0 & 0.53 & 0 & 0 & 0 & 0 & 0.80 & 0 & 0 & 0 & 0 \\
\hline SED & 7.0 & 1.446 & 2.151 & 1.435 & 1.699 & 1.195 & 0.681 & 1.164 & 1.239 & 0.999 & 0.282 & 0.896 & - \\
\hline
\end{tabular}

1 From Allan et al. 1991. 
1990. Plant numbers were greater with the New Zealandbred cultivars than with the North American cultivars.

\section{Discussion}

These results highlight concerns about the feasibility of natural reseeding for the persistence of birdsfoot trefoil stands in the drier hill and high country of the South Island. For successful natural reseeding, consideration must be given to ecological factors.

Van Keuren \& Davis (1968) concluded that inappropriate grazing management can lead to a decline in birdsfoot trefoil numbers and grazing through the flowering period will diminish seed production. At Ardlui, summer spelling over the flowering period resulted in a large increase in autumn seedling emergence, whereas grazing throughout the flowering period resulted in poor seedling emergence. A summer spelling during the flowering period is critical if plant recruitment by natural reseeding is deemed necessary.

It was not unexpected that spring seedlings failed to persist at either site as soil moisture deficits from November to April are common (Douglas et al. 1988). The establishment and survival of autumn seedlings appears better owing to more favourable moisture conditions, although at Ardlui mortality at an early stage was high, with few seedlings contributing to the stand after 12 months, under dry conditions. Frost heave in autumn following hard grazing reduces the protective effect of vegetative cover for developing seedlings and is likely to result in fewer established seedlings.

At Ardlui an above-average rainfall in autumn 1991 (36\% above normal expected rainfall for April) resulted in early germination and increased parent plant cover ensuring adequate seedling growth for survival over the following summer. This result implies that natural reseeding cannot be relied upon to improve birdsfoot trefoil plant populations without favourable climatic conditions through the spring or autumn period.

Rhizobium capable of infection is essential for seedling recruitment of birdsfoot trefoil. Lowther \& Patrick (1993) demonstrated the importance of rhizobium movement in the soil for establishing new seedlings, and that maximum rates of spread of root nodule bacteria of $<0.25$ and $4.0 \mathrm{~m}$ per year laterally and downslope respectively should be expected and although these sites were summer dry environments, root-nodule bacteria movement could be expected during the period of favourable soil moisture in the autumn to spring period.

Although there were some differences in seedling emergence between cultivars and lines, none had superior natural reseeding in these dry hill and high country regions.

\section{Summary}

Problems with birdsfoot trefoil stand performance and persistence in the drier hill and high country of the South Island can be addressed by natural reseeding, provided stand management promotes seed production and climatic conditions are favourable for seedling survival. Further research is required for techniques to improve seedling survival and plant recruitment for persistence stands of birdsfoot trefoil in the drier hill and high country of New Zealand.

\section{ACKNOWLEDGEMENTS}

The authors wish to thank Marye McGregor for technical assistance and farmers Sam Inder and Dick Wardell for providing experimental sites.

\section{REFERENCES}

Allan, B.E.; Keoghan, J.M.; Chapman, H.M.; Fraser, W.J.; Doney, R.J.; Trainor, K.D. 1991. Birdsfoot trefoil and black mountain rye: On-farm trials in the South Island hill and high country. Proceedings of the Agronomy Society of New Zealand 20: 45-49.

Chapman, H.M.; Lowther, W.L.; Trainor, K.D. 1990. Some factors limiting the success of Lotus corniculatus in hill and high country. Proceedings of the NZ Grassland Association 51:147-150.

Douglas, M.H.; Allan, B.E.; Pedofsky, J.F. 1988. Tara Hills High Country Research Station, an outline. MAFTech Bulletin.

Keoghan,_J.M.;Allan,-B.E.;-Chapman-H.M-;-Fraser; W.J.; Bates, J.; Booker, J.; Wardell, R.T.; Inder, S.B.; Kane, A. 1989. On-farm investigative development - A partnership between farmers, consultants and scientists. Proceedings of the NZ Grassland Association 50: 163- 168.

Lowther, W.L.; Patrick, Heather N. 1993. Spread of Rhizobium and Bradyrhizobium in soil. Soil biology and biochemistry 25: 607-612.

Miller, J.D.; Kreitlow, K.W.; Drake, C.R.; Henson, P.R. 1964. Stand longevity studies with birdsfoot trefoil. Agronomy journal 56: 137: 139,

Scott, D.; Charlton, J.F.L. 1983. Birdsfoot trefoil (Lotus corniculatus) as a potential dryland herbage legume in New Zealand. Proceedings of the NZ Grassland Association 44: 98-105.

Seaney, R.R.; Henson, P.R. 1970. Birdsfoot trefoil. Advances in agronomy 22: 119- 157.

Taylor, T.H.; Templeton Jr, W.C.; Wyles, J.W. 1973. Management effects on persistence and productivity of birdsfoot trefoil (Lotus corniculatus L.). Agronomy journal 65: 646-648. 
Van Keuren, R.W.; Davis, R.R. 1968. Persistence of birdsfoot trefoil, Lotus comiculatus L. as influenced by plant growth habit and grazing management. Agronomy journal 60: 92-95.

Widdup, K.H.; Keoghan, J.M.; Ryan, D.L.; Chapman, H. 1987. Breeding Lotus comiculatus for South Island tussock country. Proceedings of the NZ Grassland Association 48: 119-124. 